\title{
Antifertility effects of GnRH
}

\author{
H. M. Fraser \\ M.R.C. Unit of Reproductive Biology, Centre for Reproductive Biology, 37 Chalmers Street, \\ Edinburgh EH3 9EW, U.K.
}

\section{Introduction}

The time of this symposium coincides with the tenth anniversary of the structural characterization of gonadotrophin-releasing hormone $(\mathrm{GnRH})$ (Matsuo, Baba, Nair, Arimura \& Schally, 1971). There were then high expectations that GnRH would not only be of help in the treatment of infertility but, with the synthesis of inhibitory analogues, could also hold the key to new methods of contraception (Guillemin, 1972). It is appropriate that we should now consider this 'old' peptide in a new light because in spite of all the varied predictions no-one could have foretold some of the ways the story of GnRH has developed. For example, GnRH and its stimulatory analogues have been of only limited success in the treatment of infertility, but they now constitute our most promising approach to contraception. Studies of the way in which GnRH can change from having a stimulatory to an inhibitory effect on the pituitary gland and gonads have added a new dimension to our understanding of reproduction. For example, we now know that GnRH and its analogues can have a direct inhibitory action, both at the level of the pituitary gland and the gonads (Rippel \& Johnson, 1976; Hsueh \& Erickson, 1979a, b), receptors have been demonstrated for GnRH on the Leydig cell and ovary, and finally there is the recent discovery of a "gonadocrinin" or GnRH-like factor in the ovary and testis (Clayton, Harwood \& Catt, 1979; Sharpe \& Fraser, 1980a, b; Ying, Ling, Bohlen \& Guillemin, 1981).

It is the purpose of this paper to review the ways in which GnRH can be manipulated to produce antifertility effects and to evaluate the most promising approaches to contraception. There are 3 different ways of interfering with fertility by manipulating the GnRH stimulation of the pituitary gland: (1) GnRH can be prevented from reaching its pituitary receptors by neutralization of GnRH in the hypophysial portal blood by antibodies; (2) the GnRH receptors can be blocked by chemical antagonists of GnRH; and (3) GnRH agonists exert inhibitory effects when given chronically.

\section{Antifertility effects of GnRH in the male}

\section{GnRH antibodies}

The effects of inhibiting GnRH were first demonstrated by actively immunizing rats and rabbits against the synthetic peptide so that the antibodies that were produced neutralized endogenous GnRH. This inhibited the pituitary output and reduced the content of luteinizing hormone ( $\mathrm{LH})$ and follicle-stimulating hormone (FSH) in the blood, severely impaired testosterone production and spermatogenesis and caused the testis to involute to $10-20 \%$ of the normal weight (Arimura et al., 1973; Fraser \& Gunn, 1973; Fraser, Gunn, Jeffcoate \& Holland, 1974; Sharpe \& Fraser, 1979). Similar changes have also been observed in GnRH-immunized marmoset monkeys (Hodges \& Hearn, 1977) and rhesus monkeys (Chappel, Ellinwood, Huckins, Herbert \& Spies, 1980). Because the inhibitory effects of the immunization are so 
severe, its use as a contraceptive in man has not been considered but there is potential in the veterinary field for a non-surgical method of castration, particularly in meat production (Fraser, 1980a; Short, 1980; Robertson, Wilson, Rowland \& Fraser, 1981).

Passive transfer of antiserum to GnRH is probably the most effective and clearly defined way of inducing immediate selective inhibition of the releasing hormone, and this technique has been of considerable help in elucidating the physiological role of GnRH. For example, some of the best evidence that the pulsatile release of LH from the pituitary gland is dependent on GnRH stimulation immediately preceding it, is the abrupt cessation of LH pulses from the pituitary which follows an intravenous injection of antibodies to GnRH in the ram (Lincoln \& Fraser, 1979; Text-fig. 1).

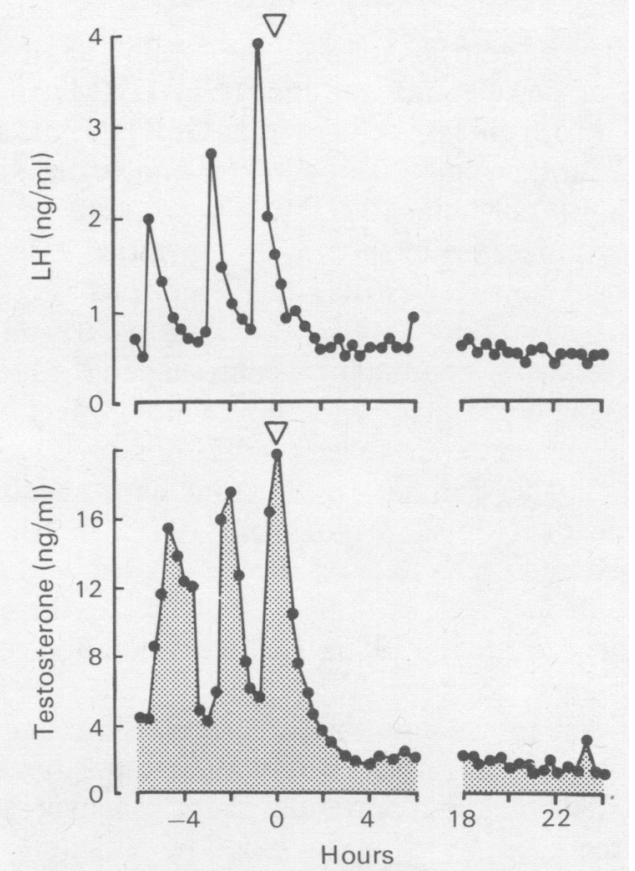

Text-fig. 1. Effect of inhibiting GnRH by an i.v. injection of $75 \mathrm{ml}$ ovine antiserum to $\mathrm{GnRH}$ (arrow) on plasma LH and testosterone concentrations in a Soay ram. (From Lincoln \& Fraser, 1979.)

\section{GnRH antagonists}

Although the synthesis of GnRH antagonists began soon after the structural characterization of GnRH, hundreds of modifications have been tested over many years to produce antagonists of a potency sufficient to give a consistent and marked inhibitory effect even in the rat (e.g. Bowers et al., 1980).

Recent developments provide new hope and encouragement with antagonists such as [Ac- $\left.\Delta^{3}-\mathrm{Pro}^{1}, \mathrm{pCl}-\mathrm{D}-\mathrm{Phe}^{2}, \mathrm{D}-\mathrm{Trp}^{3,6}, \mathrm{~N} \alpha \mathrm{MeLeu}^{7}\right] \mathrm{GnRH}$. Although the daily effective dose of about $1 \mathrm{mg}$ in the adult male rat remains considerable, this antagonist successfully decreased testosterone concentrations in the blood and inhibited spermatogenesis (Rivier, Rivier \& Vale, $1980,1981)$. Of course, as treatment progresses, the testes, seminal vesicles and prostate gland involute and the rats no longer exhibit mating behaviour. These undesirable changes can be overcome by administration of testosterone propionate in a dose which maintains libido but not fertility. There are doubts about the acceptability of a male contraceptive which would require 
testosterone replacement to maintain libido but these recent encouraging developments should promote further study of optimal dose regimens.

The mechanism of the inhibitory action of the antagonists probably resides primarily in their ability to reduce output of pituitary gonadotrophins and hence impair testosterone production (Rivier et al., 1980). Possible direct action of antagonists on the testes remains to be established.

\section{GnRH agonists}

Over the past few years most interest has been devoted to the inhibitory effects observed after chronic treatment with high doses of GnRH or its stimulatory analogues. There is irony not only in the fact that the agonists were originally developed to treat infertility, but also because these effects first came to light many years ago, during toxicity trials for GnRH, but were ill-understood and received scant attention. Thus daily treatment of rats and dogs with high doses of GnRH or amounts as low as $50 \mathrm{ng} \mathrm{GnRH}$ agonist in rats induces low plasma concentrations of testosterone (Text-fig. 2), involution of the testes, seminal vesicles and prostate gland (see Labrie et al., 1980; Sandow, von Rechenberg, Baeder \& Engelbart, 1980a; Fraser, 1981a for reviews).

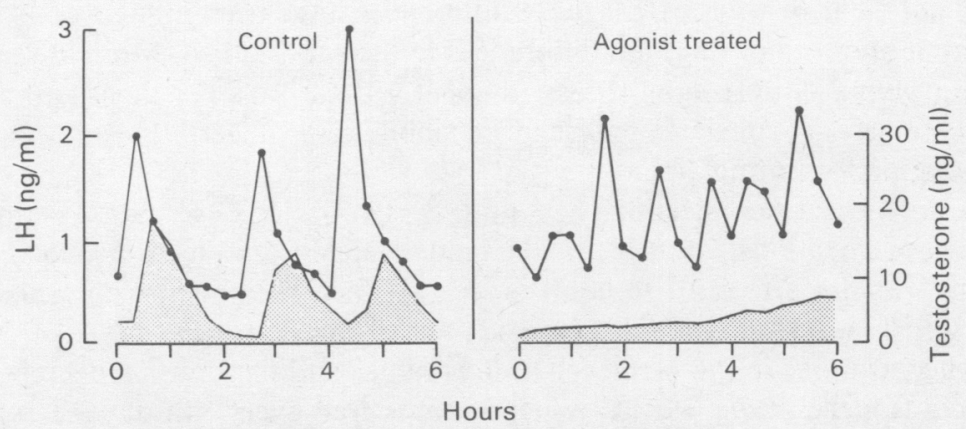

Text-fig. 2. Plasma levels of $\mathrm{LH}$ and testosterone (shaded area) in a control Soay ram and a ram $24 \mathrm{~h}$ after receiving the last of 8 consecutive once daily injections of $10 \mu \mathrm{g} \mathrm{D}$-Ser $\left(\mathrm{BU}^{\mathrm{t}}\right)^{6}$-des Gly ${ }^{10}$ GnRH ethylamide, Comparison with Text-fig. 1 shows how testosterone secretion can be reduced both by depriving the pituitary gland of endogenous GnRH and by overstimulating the pituitary gland by the GnRH agonist treatment. (From Fraser \& Lincoln, 1980.)

With the demonstration of down regulation of Leydig cell receptors for $\mathrm{LH} /$ human chorionic gonadotrophin (hCG) by hCG (Sharpe, 1976) attention focussed on the mechanism of the inhibitory effects of GnRH and its agonists. These could also be explained in part by the exposure to high levels of $\mathrm{LH}$ after agonist administration. Thus, there was a marked reduction in testicular LH receptors (Auclair, Kelly, Coy, Schally \& Labrie, 1977; Sharpe, Fraser \& Sandow, 1979; Rivier et al., 1979; Sharpe \& Fraser, 1980c) and the in-vitro steroidogenic responsiveness of the testis (Dufau et al., 1979; Sharpe et al., 1979; Sharpe \& Fraser, 1980c). Although there is a release of massive amounts of gonadotrophins after the initial exposure to GnRH agonist, repeated daily administration produces a rapid decrease in pituitary responsiveness which soon levels out to remain at a similar level during many months of treatment (Wiegelmann, Solbach, Kley \& Kruskemper, 1977; Bergquist, Nillius, Bergh, Skarin \& Wide, 1979a; Fraser \& Lincoln, 1980; Sharpe \& Fraser, 1980c). This seems to represent a reduced ability of the pituitary gland to release LH over a prolonged period and may be a reflection of a reduced ability of the gonadotrophs to synthesize new LH and transport existing stores to a releasable pool.

It therefore appeared that the persistent inhibitory effects observed at the testicular level might not be wholly attributable to the elevated concentrations of LH in the blood. A disruption 
of the normal pattern of pulsatile release of LH is another possibility (Fraser \& Lincoln, 1980; Sharpe \& Fraser, 1980c). Most attention has been focussed on the direct inhibitory action of GnRH agonists which was suggested by the demonstration that agonists caused a decrease in testicular LH/hCG receptors and inhibited testicular steroidogenesis in hypophysectomized rats (Hsueh \& Erickson, 1979b; Arimura, Serafini, Talbot \& Schally, 1979). This concept received further support from the demonstration of receptor sites for $\mathrm{GnRH}$ on the Leydig cell (Sharpe \& Fraser, 1980a). The stimulation of a GnRH-like factor by the testes after administration of hCG indicated that high doses of GnRH and its agonists might mimic the action of a naturally produced intra-gonadal regulator, the normal function of which was to reduce the responsiveness of the Leydig cells (Sharpe \& Fraser, 1980b; Sharpe, Fraser, Cooper \& Rommerts, 1981; Sharpe, 1982).

The question of whether GnRH agonists could be developed for male contraception rests on their ability to inhibit spermatogenesis. Most work has been done on the rat, but there is a disagreement in the literature about their efficacy in inducing infertility. There have been reports of a severe impairment of spermatogenesis in adult male rats (Labrie et al., 1978; Pelletier et al., 1978; Rivier et al., 1979) while others describe a less drastic reduction in testicular weight with only partial impairment of spermatogenesis and no inhibitory effect on fertility (Sandow et al., $1980 \mathrm{a}, \mathrm{b})$. It is not clear to what extent these differences have been influenced by different dose regimens, different agonists or to strain differences in the rats studied. More limited studies have been carried out giving GnRH agonist less frequently than once per day (Labrie et al., 1978); perhaps this type of approach might lead to inhibition of fertility but maintain enough testosterone secretion for normal libido.

When men were given s.c. injections of $5 \mu \mathrm{g}$ D-Ser $\left(\mathrm{Bu}^{\mathrm{t}}\right)^{6}$-des $\mathrm{Gly}{ }^{10} \mathrm{GnRH}$ ethylamide for 17 weeks, basal concentrations of LH, FSH and testosterone in the blood declined but spermatogenesis was not affected (Bergquist et al., 1979a). Treatment with a higher dose of 50 $\mu \mathrm{g}$ D-Trp ${ }^{6}$-des Gly ${ }^{10} \mathrm{GnRH}$ ethylamide given s.c. for 10 weeks, caused oligospermia in men, but testosterone concentrations in the blood fell to low values and there was a decrease in libido and other side effects (Doelle et al., 1981). When administered every 4th day, the agonist reduced sperm numbers but not to levels associated with subfertility. Thus, in men, GnRH agonists seem to be able to induce infertility at a daily dose which is much less than would be required for a $\mathrm{GnRH}$ antagonist to make male rats infertile. However, when oligospermia is induced it seems inevitable that this would be accompanied by a decrease in testosterone production and involution of the seminal vesicles and prostate gland. As with the antagonists, this would lead to the necessity for testosterone replacement treatment.

The ability of chronic GnRH agonist treatment to reduce testosterone concentrations in the blood might prove useful in the treatment of precocious puberty or of cancer of the prostate gland, with or without concomitant antiandrogen therapy (Labrie et al., 1980; Faure, Lemay, Belanger, Raynaud \& Van der Ohe, 1981).

\section{Antifertility effects of $\mathrm{GnRH}$ in the female}

\section{GnRH antibodies}

Injection of antibodies to $\mathrm{GnRH}$ before the preovulatory $\mathrm{LH}$ surge, abolishes the surge and ovulation in the rat and hamster (see Fraser, 1980a, for review) and in the ewe (H. M. Fraser \& A. S. McNeilly, unpublished observations). In the rhesus monkey, the oestrogen-induced LH surge does not appear to be inhibited by similar treatment, suggesting that primates are less dependent on hypothalamic stimulation for the LH surge to occur (McCormack, Plant, Hess \& Knobil, 1977).

Long-term inhibition of LH-RH by active immunization causes inhibition of ovulation in primates as well as in rodents. The process takes $2-3$ months to show maximal effect but during 
this time there is a gradual decrease in the release and synthesis of the pituitary gonadotrophins. This reduces follicular growth and secretion of oestradiol-17 $\beta$, thus preventing ovulation and causing involution of the ovaries and uterus (rat: Fraser \& Baker, 1978; Takahashi, Ford, Yoshinaga \& Greep, 1978; ewe: Clarke, Fraser \& McNeilly, 1978; marmoset monkey: Hodges \& Hearn, 1977; stumptailed macaque: Fraser, 1980a). With this prolonged inhibition of pituitary function the normal LH surge in response to oestrogen is abolished (ewe: Fraser, Clarke \& McNeilly, 1981; stumptailed macaque: H. M. Fraser, unpublished observations). From the point of view of practical application, it is true that successful immunization induces infertility (e.g. Fraser \& Baker, 1978) but there are disadvantages in that oestrogen concentrations in the blood may be reduced to suboptimal levels and individual variation in the immune response can lead to incomplete inhibition of follicular growth and variations in the return to normal cyclicity if antibody levels are left to decline naturally (Fraser, 1980a).

\section{GnRH antagonists}

The first group of GnRH antagonists with amino acid substitutions at positions 2,3 and 6 were able to inhibit ovulation in rats and hamsters but milligram doses were required (e.g. de la Cruz, Coy, Vilchez-Martinez, Arimura \& Schally, 1976). Later antagonists based on a 1,2,3,6-tetra-substituted GnRH sequence could be used at $200 \mu \mathrm{g}$ to inhibit ovulation (Bowers $e t$ al., 1980). The testing of the anti-ovulatory properties of these antagonists in primates has been particularly frustrating. The timing of the LH surge cannot be accurately predicted as in the laboratory rat and administration of as much as 6 doses of $50 \mathrm{mg}$ antagonist (<GluPro $\left.^{1}, \mathrm{D}-\mathrm{Phe}^{2}, \mathrm{D}-\mathrm{Trp}^{3,6}-\mathrm{GnRH}\right)$ at 8 -h intervals before the LH surge in rhesus monkeys had only limited success in preventing ovulation (Wilks et al., 1980). Wilks et al. (1980) point out that antagonists will probably have to be administered early in the follicular phase of the cycle to prevent sensitization of the anterior pituitary gland by oestradiol-17 $\beta$ from the developing follicle. The use of antagonists to prevent ovulation in women will probably, therefore, be dependent on the use of high doses of peptide over several days in the follicular phase of the cycle.

The testing in primates of the new more potent antagonists capable of preventing ovulation at a dose of less than $100 \mu \mathrm{g}$ per rat (Rivier et al., 1980) is awaited with interest. It will also be important to determine whether the corpus luteum could be a target for these GnRH antagonists, and whether the powerful antagonists can exert any direct effects on the ovary.

\section{GnRH agonists}

In marked contrast with the difficulties encountered using antagonists it is now firmly established that microgram doses of $\mathrm{GnRH}$ agonists can inhibit a wide range of reproductive functions in women and other primates. Inhibition of ovulation by chronic treatment with agonists has undoubted potential as a new method of contraception while the induction of inadequate luteal function, premature luteolysis, and inhibition of implantation and pregnancy are also targets of these inhibitory actions (for reviews, see Corbin et al., 1978; Fraser, 1981a).

Several years ago it was observed that high doses of GnRH or its agonists prevented implantation when administered to rats on Days 1-7 of pregnancy, and caused abortion when given on Days 7-12 (Bex \& Corbin, 1978). Because the hormonal requirements for implantation and pregnancy in rats and women differ considerably, clinical applications of these findings have not been forthcoming, but some important observations have been made on women. Administration of GnRH agonist daily from the time of ovulation results in an inadequate luteal phase in women, i.e. progesterone levels are lower than normal but the length of the cycle remains the same (Koyama, Ohkura, Kumasaka \& Saito, 1978; Bergquist, Nillius \& Wide, 1980a; Text-fig. 3). Administration of GnRH or its agonists (50 $\mu$ g s.c. or $500 \mu \mathrm{g}$ intranasally) 
for 2 days at the mid-luteal phase of the cycle in women and in the monkey (Macaca fascicularis) can induce premature luteolysis and menstruation (Casper \& Yen, 1979; Lemay, Labrie, Belanger \& Raynaud, 1979; Bergquist et al., 1980b; Raynaud, Mary, Moguilewsky, Mouren \& Labrie, 1980; Lemay \& Faure, 1981). However, no apparent effect on luteal function is observed if a low dose of agonist is given at the mid-luteal phase or if the luteolytic dose of agonist is administered for a 2-day period in the early part of the luteal phase (Casper, Sheehan, Erickson \& Yen, 1980a; Bergquist et al., 1980a).

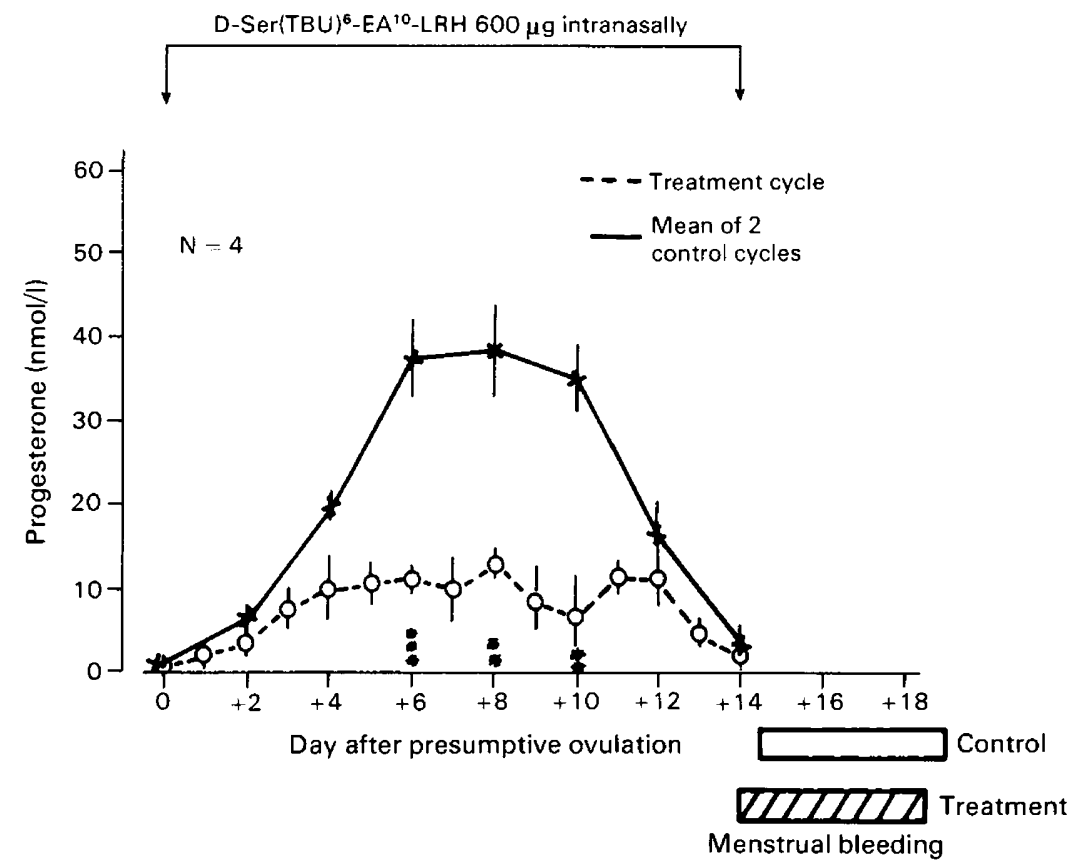

Text-fig. 3. Effect of daily intranasal administration of $600 \mu \mathrm{g}$ D-Ser(BU') ${ }^{6}$-des $\mathrm{Gly}^{10} \mathrm{GnRH}$ ethylamide, from the time of presumptive ovulation, on serum progesterone concentrations and onset of menstrual bleeding in 4 women. (From Bergquist et al., 1980a.) Values are mean \pm s.e.m. ${ }^{* *} P<0.01 ;{ }^{* * *} P<0.001$.

The mechanisms by which GnRH and its agonists may induce these changes involve decreased pituitary responsiveness, exposure of the corpus luteum to high concentrations of LH, and a direct action on the ovary. The last two mechanisms seem the most likely although virtually all the biochemical studies have been confined to the rat. Thus, the elevated LH concentrations induced by agonist administration cause an inhibition of ovarian LH and FSH receptors and function (Kledzik, Cusan, Auclair, Kelly \& Labrie, 1978). The more recent argument that GnRH agonists can have a direct inhibitory effect on the corpus luteum is based on the fact that there are receptors on the corpus luteum for $\mathrm{GnRH}$ and its agonists and $\mathrm{GnRH}$ can inhibit progesterone secretion by rat luteal cells in vitro (Clayton et al., 1979).

One problem in using luteolytic agents for contraception is that their action may be prevented by the presence of hCG, produced after implantation. When hCG was administered with the GnRH agonist in a regimen that normally caused luteolysis, the life of the corpus luteum was prolonged (Bergquist et al., 1980b; Casper, Sheehan \& Yen, 1980b). Also, in preliminary studies, 4 women in early pregnancy given 50 or $500 \mu \mathrm{g} \mathrm{GnRH}$ agonist on 2 consecutive days failed to abort or show any change in blood progesterone values (Casper $\mathrm{et} \mathrm{al \text {, }}$ 1980b). Correspondingly, the inhibitory actions of GnRH on progesterone secretion by rat luteal cells in vitro can be overcome by high concentrations of hCG (Clayton et al., 1979). More 
optimistic results were obtained by Vickery \& McRae (1980) who found that implantation of pellets of GnRH agonists during the luteal phase of rhesus monkeys overcame the stimulatory action of exogenous hCG for extending the life-span of the corpus luteum. It may still be possible to induce a contraceptive action in women by using higher doses of agonist, more prolonged administration or by administration just before implantation.

In many respects a simpler approach is to abolish ovulation entirely by continued daily administration of $\mathrm{GnRH}$ agonist. From studies in women and the stump-tailed monkey (Macaca arctoides) it has been established that a daily subcutaneous injection of as little as $5 \mu \mathrm{g}$ or administration of 400-600 $\mu \mathrm{g} \mathrm{D-Ser}(\mathrm{But})^{6}$-des Gly ${ }^{10} \mathrm{GnRH}$ ethylamide intranasally can prevent ovulation (Nillius, Bergquist \& Wide, 1978; Bergquist et al., 1979b; Fraser, Laird \& Blakeley, 1980; Text-fig. 4). Studies on the efficacy, hormonal changes, acceptability, reversibility and safety of GnRH agonists have been carried out in women (3-6 months) and in stump-tailed monkeys (13-16 months) (Text-fig. 5). No pregnancies occurred in women taking no other form of contraception apart from daily intranasal administration of $400 \mu \mathrm{g}$ (Schmidt-Gollwitzer, Hardt, Schmidt-Gollwitzer \& Nevinny-Stickel, 1981) or $600 \mu \mathrm{g}$ (Bergquist et al., 1979b) GnRH agonist. Ovulations were absent or, in a few cases, progesterone concentrations in the blood rose but to lower levels than in a normal cycle, indicating luteinization of the follicle or inadequate luteal function after ovulation. Similar results were obtained in 6 of 9 stump-tailed monkeys receiving a daily s.c. injection of $5 \mu \mathrm{g} \mathrm{GnRH}$ agonist, while in the remaining 3 animals there were some cycles with normal blood progesterone concentrations and these monkeys had to be given a higher dose to suppress ovulation (Fraser, 1980b, 1981b). In these studies individual variations were observed in the concentrations of oestradiol- $17 \beta$ in the blood. For example, in about one third of the individuals there was apparently little follicular development as indicated by continued low concentrations of oestradiol-17 $\beta$ with little or no vaginal bleeding. In the remainder there were phases of follicular development as indicated by rising oestradiol-17 $\beta$. These individuals tended to have normal-type menses or 'spotting' at regular or irregular intervals (Bergquist et al., 1979b; Fraser, 1980b; Schmidt-Gollwitzer et al., 1981; Text-fig. 5).

The pattern of oestradiol-17 $\beta$ secretion during GnRH agonist administration to prevent ovulation requires careful consideration. Although the agonist itself is probably devoid of direct side-effects, the change in exposure to oestrogen in the absence of progesterone can have important consequences. Low levels of oestradiol-17 $\beta$ might lead to menopausal symptoms,

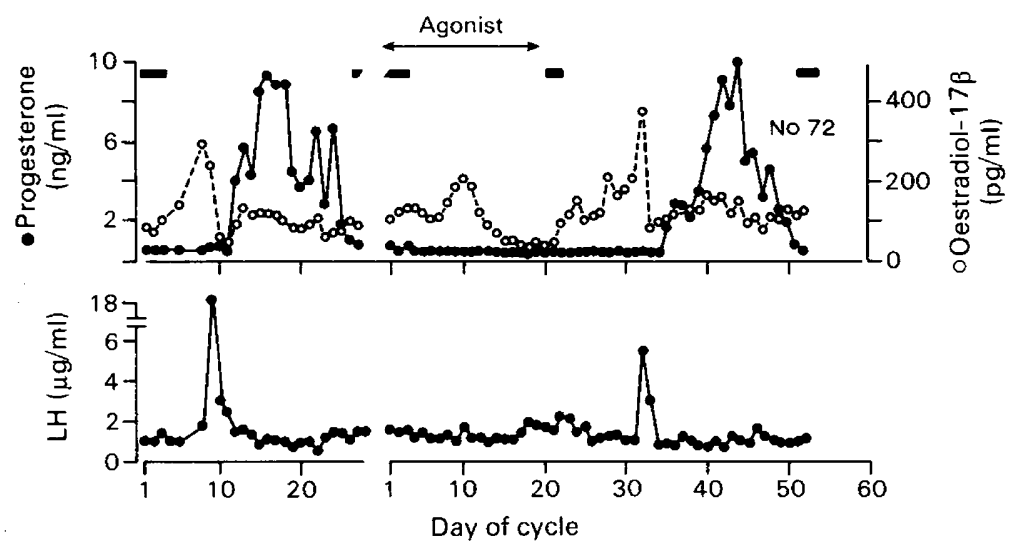

Text-fig. 4. Effect of daily subcutaneous injection of $5 \mu \mathrm{g}$ D-Ser(BUt $)^{6}$-des $\mathrm{Gly}^{10} \mathrm{GnRH}$ ethylamide for Days 1-20 of the menstrual cycle of a stump-tailed macaque on plasma concentrations of progesterone, oestradiol-17 $\beta$ and LH. Control cycle is shown on the left-hand side and post-treatment cycle on the right-hand side. Bars indicate vaginal bleeding. (From Fraser et al., 1980.) 

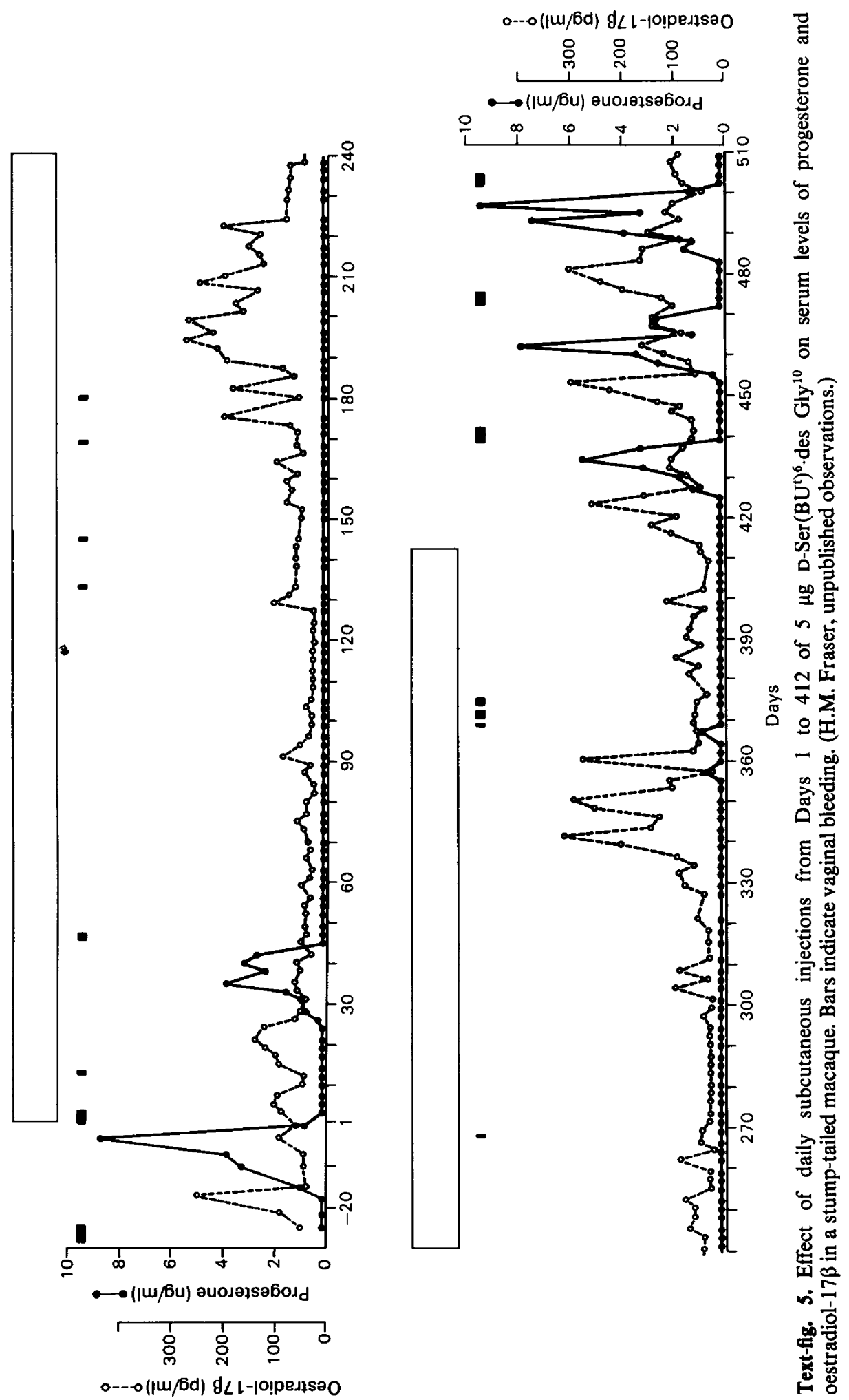
although none has been reported to date, while high concentrations of oestradiol-17 $\beta$ in the blood could lead to proliferation of the endometrium with a risk of malignant change. Morphological examinations of the uterus in women and stump-tailed monkeys have revealed a range of activity. Most endometria resembled the early follicular phase of the cycle while a small number had indications of hyperplasia (Fraser, 1981a; Schmidt-Gollwitzer et al., 1981).

Reversibility is another crucial consideration and here results appear encouraging, with normal cycles resuming with little or no delay after cessation of the treatment.

The sites of the inhibitory actions of GnRH agonists in inhibiting ovulation are the pituitary gland and the ovarian follicle. Daily blood samples taken during the first treatment cycles (Fraser et al., 1980; Text-fig. 4) show that some follicular maturation takes place, as indicated by a rise in blood oestradiol-17 $\beta$ values but the high levels of $\mathrm{LH}$ induced, and the disturbance of the normal pattern of $\mathrm{LH}$ pulses to which the follicle is normally exposed, presumably cause a disruption in the maturation process. This can be induced in women by administering hCG during the follicular phase (Friedrich, Kemeter, Salzer \& Breitenecker, 1975) and in the rat treatment with agonist results in a loss of LH and FSH receptors on the ovary (Cusan et al., 1979).

Although the concept of direct inhibitory actions of GnRH on the ovary has generated much excitement recently, the effects were glimpsed several years ago. Rippel \& Johnson (1976) found that, surprisingly, even in the hypophysectomized rat, GnRH agonist could still inhibit hCG-induced ovarian and uterine weight gain. Ying \& Guillemin (1979) demonstrated that gonadotrophin-induced ovarian weight gain in hypophysectomized immature rats could be blocked by GnRH agonist in a dose-dependent manner, as little as $80 \mathrm{ng}$ agonist twice daily being effective. In addition, the agonist prevented hCG-induced ovulation in these animals. Binding sites for GnRH are present on rat granulosa cells (Clayton et al., 1979; Jones, Conn, Marian \& Hsueh, 1980) and GnRH agonist inhibits the FSH-induced stimulation of oestrogen and progesterone by granulosa cells from immature hypophysectomized rats (Hsueh \& Erikson, 1979a). Furthermore, GnRH may mimic the action of ovarian gonadocrinin which may normally be involved in inducing follicular atresia (Ying et al., 1981; Sharpe, 1982).

In addition, pituitary responsiveness is reduced after chronic treatment with $\mathrm{GnRH}$ agonists (Bergquist et al., 1979c; Fraser et al., 1980) and the LH surge is inhibited (Fraser et al., 1980). Administration of oestradiol benzoate, which causes an LH surge in normal monkeys, fails to induce a surge or causes only a diminished or delayed rise in LH in stump-tailed macaques treated chronically with GnRH agonist (Fraser, 1981b; Text-fig 6). Since the pituitary gland is normally exposed to pulses of $\mathrm{GnRH}$ from the hypothalamus and since this is particularly important in the primate for the action of oestrogen on the anterior pituitary gland to release $\mathrm{LH}$ (see Knobil, 1980, for review), then it is likely that the LH surge is inhibited primarily because the pituitary has been exposed to prolonged stimulation by the agonist. Important changes must therefore be taking place within the gonadotrophs. One target may be the increase in releasable $\mathrm{LH}$ and activation of stored hormone or synthesis of new LH which appears to occur before mid-cycle (Hoff, Lasley, Wang \& Yen, 1977; de Kretser, Burger \& Dumpys, 1978); these mechanisms may be directly affected by chronic treatment with GnRH agonist. Furthermore, it is also likely that some reduction in pituitary content of gonadotrophins occurs after chronic treatment with GnRH agonist (Sandow, von Rechenberg, Jerzabek \& Stoll, 1978).

Another way in which chronic treatment with GnRH agonist could inhibit the oestrogeninduced LH surge is by interfering with changes in pituitary $\mathrm{GnRH}$ receptors. We do not know how the agonist treatment is affecting GnRH receptors, but, in the normally cyclic rat, $\mathrm{GnRH}$ receptors are highest on the morning of pro-oestrus and this rise may be induced by oestradiol$17 \beta$ acting directly on the pituitary gland or by changing the pattern of GnRH release (Clayton, Solano, Garcia-Vela, Dufau \& Catt, 1980).

We cannot yet say just how all these mechanisms work together but they present an impressive number of sites on which the agonists may exert effects that lead to contraception. 

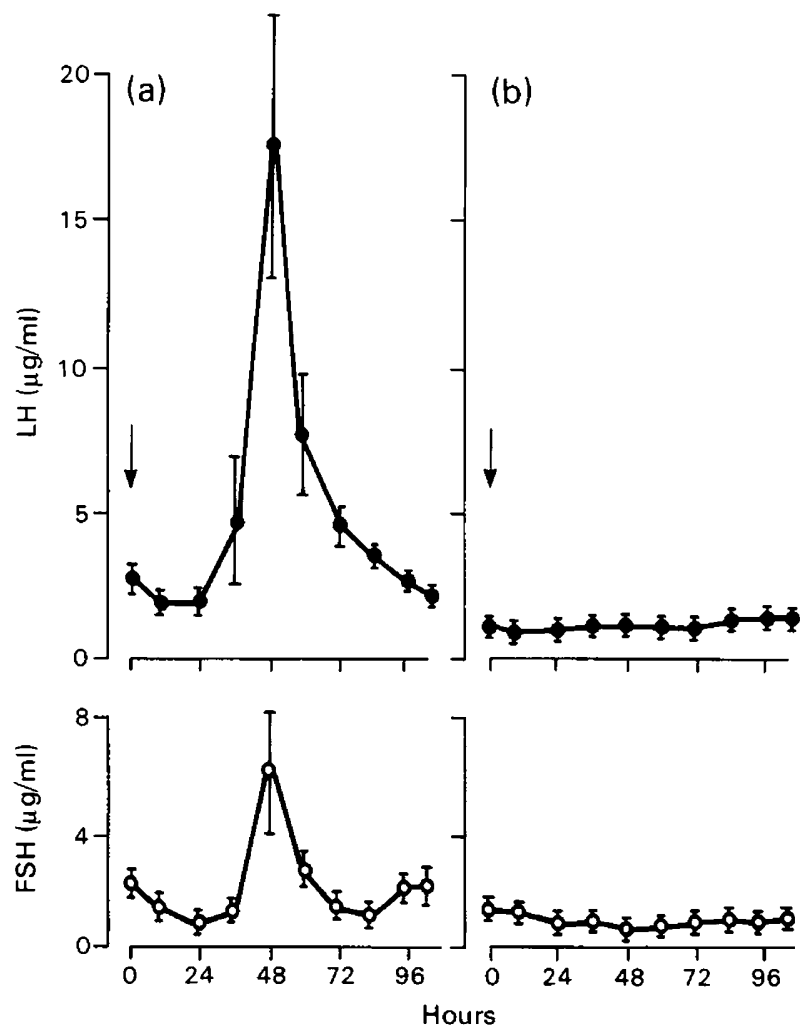

Text-fig. 6. Effect of a subcutaneous injection (arrow) of oestradiol benzoate ( $50 \mu \mathrm{g} / \mathrm{kg}$ body weight in arachis oil) on serum concentrations (mean \pm s.e.m.) of LH and FSH in (a) 4 control stump-tailed macaque monkeys on Days 1-5 of the menstrual cycle and (b) 9 animals who had received daily subcutaneous injections of $\mathrm{GnRH}$ agonist analogue for 30-60 weeks. (Data from Fraser, 1981b.)

Chronic treatment with $\mathrm{GnRH}$ agonists to prevent ovulation has considerable promise as a new method of contraception in women, particularly for those in whom the steroidal oral contraceptives are inadvisable. The main problems to be overcome centre around the changes in ovarian steroid production induced by the treatment. While amenorrhoea would be accepted and, indeed, welcomed by many women (Loudon, Foxwell, Potts, Guild \& Short, 1977), careful investigation of endometrial morphology will have to be carried out and it may be necessary to give progesterone treatment at intervals to induce endometrial bleeding. In women in whom the agonist induces unpredictable bleeding different dose regimens may be effective in preventing this or even making the bleeding more regular.

\section{Conclusion}

GnRH can be manipulated to produce anti-fertility effects by induction of antibodies or use of antagonists and agonists. During recent years the use of agonists has received most attention and investigation of their inhibitory effects on the gonad has suggested several possible mechanisms. Inhibition of ovulation seems the most promising target for an attempt to develop these observations as a new approach to contraception. This can be achieved by injecting a few micrograms daily, or, more likely, by intranasal administration of 400-600 $\mu \mathrm{g}$. Results so far indicate no untoward effects but many years of testing lie ahead. There is the possibility that 
partners could share the responsibility for contraception by taking the same GnRH agonist for alternate periods, but to prevent spermatogenesis in men it would seem that 10 times these doses are needed and there is the additional disadvantage that libido is reduced. Finally, it is worth considering that these studies which have high-lighted the inhibitory actions of GnRH have no doubt contributed to the increased awareness of the benefits of treating gonadotrophin deficiency by low-dose pulsatile administration of GnRH (Crowley \& McArthur, 1980; Leyendecker, Wildt \& Hansmann, 1980).

\section{References}

Arimura, A., Sato, H., Kumasaka, T., Worobec, R.B., Debeljuk, L., Dunn, J. \& Schally, A.V. (1973) Production of antiserum to LH-releasing hormone (LH-RH) associated with gonadal atrophy in rabbits: development of radioimmunoassays for $\mathrm{LH}$ RH. Endocrinology 93, 1092-1103.

Arimura, A., Serafini, P., Talbot, S. \& Schally, A.V. (1979) Reduction of testicular luteinizing hormone/ human chorionic gonadotropin receptors by (D$\operatorname{Trp}^{6}$ )-luteinizing hormone releasing hormone in hypophysectomized rats. Biochem. Biophys. Res. Commun. 90, 687-693.

Auclair, C., Kelly, P.A., Coy, D.H., Schally, A.V. \& Labrie, F. (1977) Potent inhibitory activity of (D-Leu ${ }^{6}$, des-Gly-NH ${ }_{2}^{10}$ ) LHRH ethylamide on $\mathrm{LH} / \mathrm{hCG}$ and PRL testicular receptor levels in the rat. Endocrinology 101, 1890-1893.

Bergquist, C., Nillius, S.J., Bergh, T., Skarin, G. \& Wide, L. (1979a) Inhibitory effects on gonadotrophin secretion and gonadal function in men during chronic treatment with a potent stimulatory luteinizing hormone-releasing hormone analogue. Acta endocr., Copenh. 91, 601-608.

Bergquist, C., Nillius, S.J. \& Wide, L. (1979b) Intranasal gonadotrophin-releasing hormone agonist as a contraceptive agent. Lancet ii, 215-217.

Bergquist, C., Nillius, S.J. \& Wide, L. (1979c) Inhibition of ovulation in women by intranasal treatment with a luteinizing hormone-releasing hormone agonist. Contraception 19, 497-506.

Bergquist, C., Nillius, S.J. \& Wide, L. (1980a) Effects of a luteinizing hormone-releasing hormone agonist on luteal function in women. Contraception 22, 287-293.

Bergquist, C., Nillius, S.J. \& Wide, L. (1980b) Luteolysis induced by a luteinizing hormone releasing hormone agonist is prevented by human chorionic gonadotrophin. Contraception 22, 341-348.

Bex, FJ. \& Corbin, A. (1978) Mechanism of the postcoital contraceptive effect of luteinizing hormone-releasing hormone: ovarian luteinizing hormone receptor interactions. Endocrinology 105, 139-145.

Bowers, C.Y., Humphries, J., Wasiak, T., Folkers, K., Reynolds, G.A. \& Reichert, L.E. (1980) On the inhibitory effects of luteinizing hormone-releasing hormone analogs. Endocrinology 106, 674-683.

Casper, R.F. \& Yen, S.S.C. (1979) Induction of luteolysis in the human with a long-acting analog of luteinizing hormone-releasing factor. Science, N.Y. 205, $408-410$.

Casper, R.F., Sheehan, K., Erickson, G. \& Yen, S.S.C. (1980a) Neuropeptides and fertility control in the female. In Research Frontiers in Fertility Regulation, pp. 409-423. Eds G. I. Zatuchni, M. H. Labbok \& J. J. Sciarra. Harper \& Row, New York.

Casper, R.F., Sheehan, K.L. \& Yen, S.S.C. (1980b) Chorionic gonadotrophin prevents LRF-agonistinduced luteolysis in the human. Contraception 21, $471-478$

Chappel, S.C., Eltinwood, W.E., Huckins, C., Herbert, D.C. \& Spies, H.G. (1980) Active immunization of male rhesus monkeys against luteinizing hormonereleasing hormone. Biol. Reprod. 22, 333-342.

Clarke, I.J., Fraser, H.M. \& McNeilly, A.S. (1978) Active immunization of ewes against luteinizing hormone releasing hormone, and its effects on ovulation and gonadotrophin, prolactin and ovarian steroid secretion. J. Endocr. 78, 39-47.

Clayton, R.N., Harwood, J.P. \& Catt, K.J. (1979) Gonadotrophin-releasing hormone analogue binds to luteal cells and inhibits progesterone production. Nature, Lond. 282, 90-92.

Clayton, R.N., Solano, A.R., Garcia-Vela, A., Dufau, M. \& Catt, K.J. (1980) Regulation of pituitary receptors for gonadotropin-releasing hormone during the rat estrous cycle. Endocrinology 107, 699-706.

Corbin, A., Beattie, C.W., Tracy, J., Jones, R., Foell, T.J., Yardley, J. \& Rees, R. (1978) The antireproductive pharmacology of LH-RH and agonistic analogues. Int. J. Fert. 23, 81-92.

Cusan, L., Auclair, C., Belanger, A., Ferland, L., Kelly, P.A., Seguin, C. \& Labrie, F. (1979) Inhibitory effects of a long term treatment with a luteinizing hormone-releasing hormone agonist on the pituitarygonadal axis in male and female rats. Endocrinology 104, 1369-1376.

Crowley, W.F. \& McArthur, J.W. (1980) Induction of puberty in hypogonadotropic males: use of low-dose pulsatile luteinizing hormone-releasing hormone (LHRH) administration. Endocrinology 106, Suppl. p. 260, Abstr. 743 .

de Kretser, D.M., Burger, H.G. \& Dumpys, R. (1978) Patterns of serum LH and FSH in response to 4-hour infusions of luteinizing hormone releasing hormone in normal women during menstrual cycle, or oral contraceptives and in postmenopausal state. J. clin. Endocr. Metab. 46, 227-235.

de la Cruz, H., Coy, D.H., Vilchez-Martinez, J.A., Arimura, A. \& Schally, A.V. (1976) Blockade of ovulation in rats by inhibiting analogs of luteinizing hormone-releasing hormone. Science, N.Y. 191, 195-197.

Doelle, G.C., Linde, R.B., Alexander, A.N., Kirchner, F.K., Vale, W., Rivier, J. \& Rabin, D. (1981) Studies 
on D-Trp ${ }^{6}$-Pro ${ }^{9}-\mathrm{N}$-ethylamide-LHRH administration to normal males. Endocrinology 108, Suppl. 108, p. 91 , Abstr. 34.

Dufau, M.L., Cigorraga, S., Baukal, A.J., Sorrel, S., Bator, J.M., Neubauer, J.F. \& Catt, K.J. (1979) Androgen biosynthesis in Leydig cells after testicular desensitization by luteinizing hormonereleasing hormone and human chorionic gonadotropin. Endocrinology 105, 1314-1321.

Faure, N., Lemay, A., Belanger, A., Raynaud, J.P. \& Van der Ohe, M. (1981) Inhibitory effects of chronic administration of a potent LHRH agonist, (DSer(TBU) ${ }^{6}$, des-Gly- $\mathrm{NH}_{2}{ }^{10}$ ) LHRH ethylamide (Buserelin) on serum androgens in patients with cancer of the prostate. Endocrinology 108, Suppl. p. 167, Abstr. 339.

Fraser, H.M. (1980a) Inhibition of reproductive function by antibodies to luteinizing hormone releasing hormone. In Immunological Aspects of Reproduction and Fertility Control, pp. 143-171. Ed. J. P. Hearn. MTP Press, Lancaster.

Fraser, H.M. (1980b) Contraceptive effects of an agonist of luteinizing hormone releasing hormone: long-term study on the female stumptailed monkey (Macaca arctoides). J. Endocr. 85, 13p, Abstr.

Fraser, H.M. (1981a) Luteinizing hormone releasing hormone and fertility control. In Oxford Reviews of Reproductive Biology, Vol. 3, pp. 1-49. Ed. C. A. Finn. Oxford University Press.

Fraser, H.M. (1981b) Effect of oestrogen on gonadotrophin release in stumptailed monkeys (Macaca arctoides) treated chronically with an agonist analogue of LH-RH. J. Endocr. 91 (in press).

Fraser, H.M. \& Baker, T.G. (1978) Changes in the ovaries of rats after immunization against luteinizing hormone releasing hormone. J. Endocr. 77, 85-93.

Fraser, H.M. \& Gunn, A. (1973) Effects of antibodies to luteinizing hormone releasing hormone in the male rabbit and on the rat oestrous cycle. Nature, Lond. 244, 160-161.

Fraser, H.M. \& Lincoln, G.A. (1980) Effects of chronic treatment with an LH-RH agonist on the secretion of LH, FSH and testosterone in the ram. Biol. Reprod. 22, 269-276.

Fraser, H.M., Gunn, A., Jeffcoate, S.L. \& Holland, D.T. (1974) Effect of active immunization to luteinizing hormone releasing hormone on serum and pituitary gonadotrophins, testes and accessory sex organs in the male rat. J. Endocr. 63, 399-406.

Fraser, H.M., Laird, N.C. \& Blakeley, D.M. (1980) Decreased pituitary responsiveness and inhibition of the LH surge and ovulation in the stumptailed monkey (Macaca arctoides) by chronic treatment with an agonist of LH-RH. Endocrinology 106, 452-457.

Fraser, H.M., Clarke, I.J. \& McNeilly, A.S. (1981) The effect of oestrogen and LH-RH agonist on the release of gonadotrophins in ovariectomized ewes deprived of LH-RH. J. Reprod. Fert. 60, 130-141.

Friedrich, F., Kemeter, P., Salzer, H. \& Breitenecker, G. (1975) Ovulation inhibition with human chorionic gonadotrophin. Acta endocr., Copenh. 78, 332-342.

Guillemin, R. (1972) Physiology and chemistry of the hypothalamic releasing factors for gonadotropins: a new approach to fertility control. Contraception $\mathbf{5}$, $1-19$.

Hodges, J.K. \& Hearn, J.P. (1977) Effect of immunisation against luteinizing hormone releasing hormone on reproduction of the marmoset monkey Callithrix jacchus. Nature, Lond. 265, 746-747.

Hoff, J.D., Lasley, B.L., Wang, C.F. \& Yen, S.S.C. (1977) The two pools of pituitary gonadotrophin: regulation during the menstrual cycle.J. clin. Endocr. Metab. 44, 302-312.

Hsueh, A.J.W. \& Erickson, G.F. (1979a) Extra-pituitary action of gonadotropin-releasing hormone: direct inhibition of ovarian steroidogenesis, Science, N.Y. 204, 854-855.

Hsueh, A.J.W. \& Erickson, G.F. (1979b) Extra-pituitary inhibition of testicular function by luteinizing hormone releasing hormone. Nature, Lond. 281, 66-67.

Jones, P.B.C., Conn, P.M., Marian, J. \& Hsueh, A.J.W. (1980) Binding of gonadotropin releasing hormone agonist to rat ovarian granulosa cells. Life Sci. 27, 2125-2132.

Kledzik, G.S., Cusan, L., Auclair, C., Kelly, P.A. \& Labrie, F. (1978) Inhibition of ovarian LH and FSH receptor levels by treatment with (D-Ala ${ }^{6}$,des-Gly$\mathrm{NH}_{2}{ }^{10}$ )-LHRH ethylamide during the oestrous cycle in the rat. Fert. Steril. 30, 348-353.

Knobil, E. (1980) The neuroendocrine control of the menstrual cycle. Recent Prog. Horm. Res. 36, 53-88.

Koyama, T., Ohkura, T., Kumasaka, T. \& Saito, M. (1978) Effect of post-ovulatory treatment with a luteinizing hormone-releasing hormone analog on the plasma level of progesterone in women. Fert. Steril. 30, 549-552.

Labrie, F., Auclair, C., Cusan, L., Kelly, P.A., Pelletier, G. \& Ferland, L. (1978) Inhibitory effect of LHRH and its agonists on testicular gonadotrophin receptors and spermatogenesis in the rat. Int. J. Androl., Suppl. 2, 303-318.

Labrie, F., Belanger, A., Cusan, L., Seguin, C., Pelletier, G., Kelly, P., Reeves, J.J., Lefebvre, F.-A., Lemay, A., Gourdeau, Y. \& Raynaud, J.P. (1980) Antifertility effects of LHRH agonists in the male. $J$. Androl. 1, 209-228.

Lemay, A. \& Faure, N. (1981) Sensitivity of gonadotrophin and corpus luteum responses to single intranasal administration of (D-Ser(TBU) ${ }^{6}$-des-Gly$\mathrm{NH}_{2}{ }^{10}$ ] LHRH ethylamide (Buserelin) in normal women. Endocrinology 108, Suppl. p. 90, Abstr. 29.

Lemay, A., Labrie, F., Belanger, A. \& Raynaud, J.P. (1979) Luteolytic effect of intranasal administration of [D-Ser(TBU) ${ }^{6}$,des-Gly- $\left.\mathrm{NH}_{2}{ }^{10}\right]$ luteinizing hormone releasing hormone ethylamide in normal women. Fert. Steril. 32, 646-651.

Leyendecker, G., Wildt, L. \& Hansmann, M. (1980) Pregnancies following chronic intermittent (pulsatile) administration of $\mathrm{Gn}-\mathrm{RH}$ by means of a portable pump ("Zyklomat") a new approach to the treatment of infertility in hypothalamic amenorrhoea. $J$. clin. Endocr. Metab. 51, 1214-1216.

Lincoln, G.A. \& Fraser, H.M. (1979) Blockade of episodic secretion of luteinizing hormone in the ram by the administration of antibodies to luteinizing hormone releasing hormone. Biol. Reprod. 21, 1239-1245. 
Louden, N.B., Foxwell, M., Potts, D.M., Guild, A.L. \& Short, R.V. (1977) Acceptability of an oral contraceptive that reduces the frequency of menstruation: the tri-cycle pill regimen. Br. med. J. 2, 487.

Matsuo, H., Baba, Y., Nair, R.M.G, Arimura, A. \& Schally, A.V. (1971) Structure of the porcine LH-and-FSH-releasing hormone. I. The proposed amino acid sequence. Biochem. Biophys. Res. Commun. 43, 1334-1339.

McCormack, J.T., Plant, T.M., Hess, D.L. \& Knobil, E. (1977) The effect of luteinizing hormone releasing hormone (LHRH) antiserum administration on gonadotrophin secretion in the rhesus monkey. Endocrinology 100, 663-667.

Nillius, S.J., Bergquist, C. \& Wide, L. (1978) Inhibition of ovulation in women by chronic treatment with a stimulatory LRH analogue-a new approach to birth control? Contraception 17, 537-545.

Pelletier, G., Cusan, L., Auclair, C., Kelly, P.A., Desy, L. \& Labrie, F. (1978) Inhibition of spermatogenesis in the rat by treatment with [D-Ala ${ }^{6}$ des-Gly- $\mathrm{NH}_{2}{ }^{10}$ ] LHRH ethylamide. Endocrinology 103, 641-643.

Raynaud, J.P., Mary, I., Moguilewsky, M., Mouren, M. \& Labrie, F. (1980) Inhibition of progesterone secretion during the luteal phase by two luteinizing hormone-releasing hormone agonists in Macaca fascicularis. Fert. Steril. 34, 593-598.

Rippel, R.H \& Johnson, E.S. (1976) Inhibition of hCG-induced ovarian and uterine weight augmentation in the immature rat by analogs of $\mathrm{GnRH}$. Proc. Soc. exp. Biol. Med. 152, 432-436.

Rivier, C., Rivier, J. \& Vale, W. (1979) Chronic effects of [D-Trp ${ }^{6}$, Pro $\left.^{9}-\mathrm{NEt}\right]$ luteinizing hormone-releasing factor on reproductive processes in the male rat. Endocrinology 105, 1191-1201.

Rivier, C., Rivier, J. \& Vale, W. (1980) Antireproductive effects of a potent GnRH antagonist in the male rat. Science, N.Y. 210, 93-95.

Rivier, C., Rivier, J. \& Vale, W. (1981) Effect of a potent $\mathrm{GnRH}$ antagonist and testosterone propionate on mating behaviour and fertility in the male rat. Endocrinology 108, 1998-2001.

Robertson, I.S., Wilson, J.C., Rowland, A.C. \& Fraser, H.M. (1981) Further studies on immunological castration in male cattle. Vet. Rec. 108, 381-382.

Sandow, J., von Rechenberg, W., Jerzabek, G. \& Stoll, W. (1978) Pituitary gonadotropin inhibition by a highly active analog of luteinizing hormone-releasing hormone. Fert. Steril. 30, 200-209.

Sandow, J., von Rechenberg, W., Baeder, C. \& Engelbart, K. (1980a) Antifertility effects of an LH-RH analogue in male rats and dogs. Int. J. Fert. 25, 213-221.

Sandow, J., von Rechenberg, W., Jerzabek, G., Engelbart, K., Kuhl, H. \& Fraser, H.M. (1980b) Hypothalamic-pituitary-testicular function in rats after supraphysiological doses of a LHRH analogue (Buserelin). Acta endocr., Copenh. 94, 489-497.

Schmidt-Gollwitzer, M., Hardt, W., Schmidt-Gollwitzer, K. \& Nevinny-Stickel, L. (1981) Influence of the LH-RH analogue buserelin on cyclic ovarian func- tion and on the endometrium. A new approach to fertility control? Contraception 23, 187-196.

Sharpe, R.M. (1976) hCG-induced decrease in availability of rat testis receptors. Nature, Lond. 264, 644.

Sharpe, R.M. (1982) Cellular aspects of the inhibitory actions of LH-RH on the ovary and testis. J. Reprod. Fert. 64, 517-527.

Sharpe. R.M. \& Fraser, H.M. (1979) Leydig cell function in rats chronically deprived of normal gonadotrophin stimulation: the effect of treatment with hCG. Int. J. Androl. 2, 395-407.

Sharpe, R.M. \& Fraser, H.M. (1980a) Leydig cell receptors for luteinizing hormone-releasing hormone and its agonists and their modulation by administration or deprivation of the releasing hormone. Biochem. Biophys. Res. Commun. 95, 256-262.

Sharpe, R.M. \& Fraser, H.M. (1980b) hCG stimulation of testicular LHRH-like activity. Nature, Lond. 287, $642-643$.

Sharpe, R.M. \& Fraser, H.M. (1980c) Inhibition of maturational changes in Leydig cell function by treatment of rats with an agonist of LH-RH. $J$. Reprod. Fert. 60, 359-368.

Sharpe, R.M., Fraser, H.M. \& Sandow, J. (1979) Effect of treatment with an agonist of luteinizing hormone releasing hormone on early maturational changes in pituitary and testicular function in the rat. J. Endocr. 80, 249-257.

Sharpe, R.M., Fraser, H.M., Cooper, I. \& Rommerts, F.F.G. (1981) Sertoli-Leydig cell communication via an LHRH-like factor. Nature, Lond. 290, 785787.

Short, R.V. (1980) The hormonal control of growth at puberty. In Growth in Animals, pp. 25-45. Ed. T. L. J. Lawrence. Butterworths, London.

Takahashi, M., Ford, J.J., Yoshinaga, K. \& Greep, R.O. (1978) Active immunization of female rats with luteinizing hormone releasing hormone (LHRH). Biol. Reprod. 71, 754-761.

Vickery, B.H. \& McRae, G.I. (1980) Antagonism by an LHRH agonist of the steroidogenic effects of exogenous human chorionic gonadotrophin in the rhesus monkey. Life Sci. 27, 1409-1413.

Wiegelmann, w., Solbach, H.G., Kley, H.K. \& Kruskemper, H.L. (1977) LH and FSH response to long term application of LH-RH analogue in normal males. Horm. Metab. Res. 9, 521-522.

Wilks, J.W., Kolkers, K., Bowers, C.Y., Humphries, J., Schircks, B. \& Friebel, K. (1980) Inhibition of preovulatory gonadotropin secretion in the rhesus monkey by $\left[(<\text { Glu-Pro })^{1}\right.$, D-Phe ${ }^{2}$, D-Trp $\left.{ }^{3},{ }^{6}\right]-$ LHRH. Contraception 22, 313-323.

Ying, S.Y. \& Guillemin, R. (1979) (D-Trp ${ }^{6}$-Pro9-NEt)luteinizing hormone-releasing factor inhibits follicular development in hypophysectomized rats. Nature, Lond. 280, 593-595.

Ying, S.Y., Ling, N., Bohlen, P. \& Guillemin, R. (1981) Gonadocrinins: peptides in ovarian follicular fluid stimulating the secretion of pituitary gonadotropins. Endocrinology 108, 1206-1215. 